\title{
Electrochemical and Spectroscopic Studies of The Complexed Species of Models of Nitrohumic Acids derived from Phthalic Acid
}

\author{
Ana Lucia Ramalho Mercê ${ }^{* a}$, Simone Cristina Lombardi ${ }^{\mathrm{a}}$, Antonio Sálvio \\ Mangrich $^{\mathrm{a}}$, Noel Massinhan Levy ${ }^{\mathrm{b}}$, and Bruno Szpoganicz ${ }^{\mathrm{c}}$ \\ a Departamento de Química, Universidade Federal do Paraná, C.P. 19081, 81531-990 \\ Curitiba - Pr,Brazil; anamerce@quimica.ufpr.br \\ ${ }^{\mathrm{b}}$ LAC - convênio UFPR/COPEL - Paraná, Brazil \\ ${ }^{\mathrm{c}}$ Departamento de Química, Universidade Federal de Santa Catarina, SC - Brazil
}

Received: May 21, 1996

\begin{abstract}
A necessidade de se estudar compostos modelo é a de se compreender como os sítios de quelação de substâncias orgânicas complexas como os ácidos húmicos e nitro-húmicos atuam frente a um íon metálico, pois as substâncias húmicas são potenciais fertilizantes orgânicos.

As propriedades químicas principais dos complexos encontrados entre os ácidos 3-nitroftálico e 4-nitroftálico e os íons metálicos Fe(III) e Zn(II) foram estudadas por titulações potenciométricas, espectroscopia ultravioleta-visível e voltametria cíclica, e uma titulação potenciométrica experimental foi feita com uma mistura de modelos de ácidos nitro-húmicos e $\mathrm{Cu}$ (II). Calculou-se as constantes de equilíbrio para os sistemas, cujas espécies foram detectadas pelas outras técnicas empregadas. Estudos comparativos entre sítios de quelação derivados de nitrossalicilatos e nitrocatecolatos com $\mathrm{Fe}(\mathrm{III}), \mathrm{Zn}$ (II) e Cu(II) são apresentados. Neste trabalho, os ácidos nitro-húmicos, além de possuírem maior teor de nitrogênio que os ácidos húmicos, também exibiram a vantagem de que alguns centros de quelação, preferencialmente, se ligam a íons metálicos nos valores de $\mathrm{p}[\mathrm{H}]$ próximos aos valores normais do solo, 7,0 a 7,5.

The study of model compounds is necessary in order to obtain information about complex organic substances as in the case of humic substances (HS). These substances are potential organic fertilizers and have other important functions in soils, natural waters and organic sediments.

The main chemical properties of the complexes formed from 3-nitrophthalic and 4-nitrophthalic acids and the metal ions Fe(III) and $\mathrm{Zn}$ (II) were studied using potentiometric titrations, ultravioletvisible spectroscopy (UV-Vis) and cyclic voltammetry (CV). A trial potentiometric titration was done with a mixture of the models for nitrohumic acids and $\mathrm{Cu}$ (II). Equilibrium constants for the systems were calculated and UV-Vis and CV were employed to monitor the formation of the species. Comparative studies involving chelating centres of nitrosalicylic acids and nitrocatechols with $\mathrm{Fe}(\mathrm{III}), \mathrm{Zn}$ (II) and $\mathrm{Cu}$ (II) are presented. The initial studies involving the nitrohumic substances (NHS), a laboratory artifact of HS have been made and good evidence was found for the further use of NHS as a potential organic fertilizer as well as HS. In this present work one of the observed advantages of NHS over HS was that some aromatic nitro- centres can bind some metal ions at $\mathrm{p}[\mathrm{H}]$ values of normal soils, near 7.0 to 7.5 .
\end{abstract}

Keywords: metal complex, humic substances, potentiometric titration, cyclic voltammogram, speciation, organic fertilizer 


\section{Introduction}

Humic substances (HS), organic material existing in soil and waters arising from the decay of plants and animals play many roles in soils. Among them, they have long been considered as a natural source of $\mathrm{C}, \mathrm{N}, \mathrm{P}$, and $\mathrm{S}$ and also, due to their ability to form stable complexes with many metal ions, can be considered as a natural fertilizer ${ }^{1-2}$.

Many workers have made contributions concerning the determination of dissociation constants of the acidic functional groups of HS in order to obtain a better understanding of metal complexation by these organic macromolecules since the late 70's. The determination involved the use of thermochemistry ${ }^{2}$, Fourier Transform Infrared Spectrometry ${ }^{3}$, and Potentiometric studies ${ }^{4}$.

Since the contribution of Schulten and Schnitzer ${ }^{5}$ for the unraveling of the structure of HS, there have been few important contributions to the HS literature. The structure of these geopolymers is complex. However, it is known for certain that aromatic structures are present as part of the structure of HS and NHS. These macromolecules contain within their structure organic functional groups such as catechols, salicylates and phthalates, capable of complexing metal ions ${ }^{6-10}$.

Figure 1, showing the Eqs. 1 to 3, represents some of the structures capable of complexing the metal ions.

Many studies have been published ${ }^{11-17}$ of the complexing ability of HS towards metal ions like copper, nickel and aluminum as well as the $\mathrm{pH}$ dependence of these systems. Model compounds are used to overcome the difficulties of studying HS due to their physical complexity. No matter
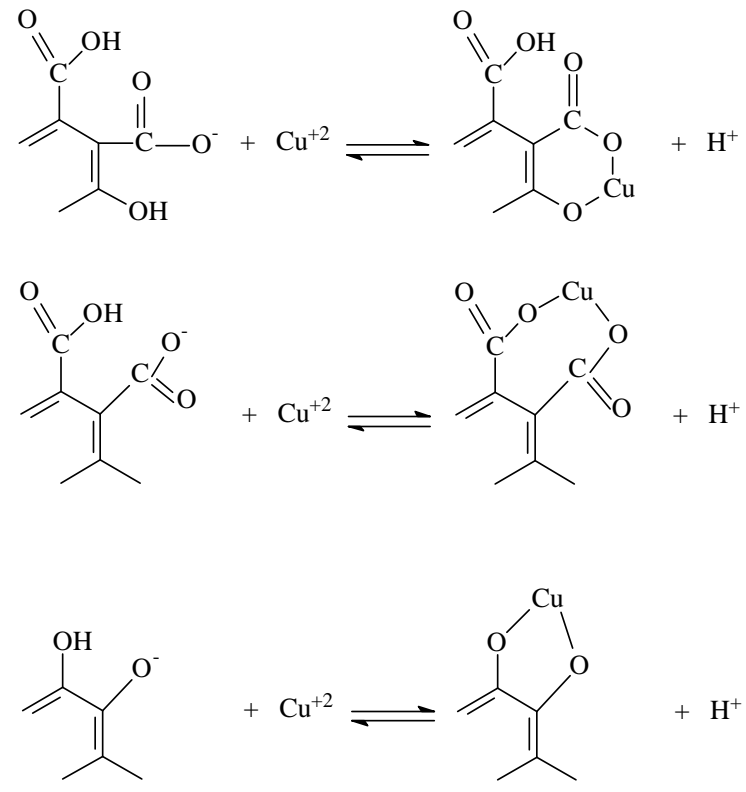

Figure 1. Some examples of how organic groups present in HS can clunch metal ions. the size of the molecules chosen, they allow for a better understanding of the complexation behaviour of HS.

Another advantage in using model compounds for the study of the behaviour of HS towards metal ion complexation lies in the fact that it is very difficult to make interpretations of the acid-base properties of HS, due to the perturbations encountered in acid-base potentiometric titrations. Various models have been proposed in the literature to take into account the mixture of chemically non identical acid sites. One of them has sought to fit experimental data empirically and is called the Discrete Ligand Approach $^{18}$. The empirical model presumes that the observed potentiometric properties are a consequence of the different acid strenghts of a limited number of functional sites that constitute the humic acid (HA) molecule. The present work is based on this model.

The nitrohumic acids (NHA), a laboratory artifact of HA obtained by the action of nitric acid upon HA, have the advantage of a higher percentage of $\mathrm{N}$ than in HA. ${ }^{9}$ The complexing ability of a model compound for the phthalic derived sites of HA is compared with the models chosen for the nitrophthalic derived sites of NHA using two important plant micronutrients, one a hard ( $\mathrm{Fe}(\mathrm{III}))$ and the other a softer Lewis acid ( $\mathrm{Zn}(\mathrm{II})$ ). The models, phthalic acid (APA), 3-nitrophthalic acid (3-NPA) and 4-nitrophthalic acid (4-NPA), are represented in Fig. 2.

Althought the models are not complex molecules, the interest for studying them, apart from what has been said above, is that there is a need to complement the data in the literature, due to the lack of certain stability constant data. Also, this study is important for evaluating the interactions of HS and NHS acid sites in the presence of metal ions, in order to understand how during their slow mineralization in soil, not only how the greater amount of $\mathrm{N}$ of NHS compared to HS, is released to plants but also how all the metal ions bound to these acidic sites, will be made available.

A comparative study is extended by collecting data from model compounds of HA and NHA, salicylic and catecholic derivatives, previously reported in the literature ${ }^{19-24}$.

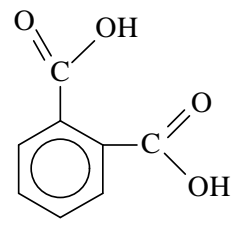

APA

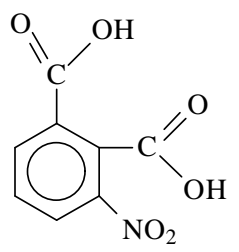

3-NPA

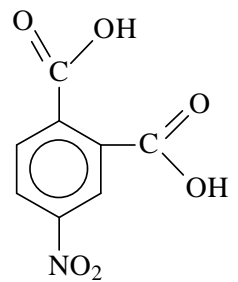

4-NPA
Figure 2. Model compounds APA, 3-NPA and 4-NPA, studied in this work. 
The study of metal ions and HA complexes has led to few conclusive results, as there are many drawbacks to attributing the binding constants found with a specific site or reactive site that is actually linked to the metal ion. In order to gather some previously reported data concerning nitrosalicylic acids ${ }^{19-20}$ and nitrocatechols ${ }^{22-23}$, a trial titration was made in a mixture of NHA models and $\mathrm{Cu}(\mathrm{II})$.

Cyclic voltammetry (CV) can give information concerning the stability of electrogenerated products in a redox system tested over a range of $\mathrm{p}[\mathrm{H}]$ values. This technique is also important in helping to identify those species involved (aqua ions, complexed species, etc) ${ }^{25}$.

Ultraviolet-visible spectroscopy (UV-Vis) shows a relation between the differences in the wavelength values of the spectra obtained in solutions of differing $\mathrm{p}[\mathrm{H}]$, the differences corresponding to the different species proposed in the equilibria ${ }^{26}$.

\section{Experimental}

\section{Chemical reagents}

All chemicals used were of analytical-reagent grade and were used as received. All solutions were made with bi-distilled, deionized and $\mathrm{CO}_{2}$ - free water.

All nitrosalicylic and salicylic acid solutions were described elsewhere ${ }^{19}$. The nitrophthalic (Sigma - USA) and phthalic acid (Reagen - Brazil) solutions were made in 5\% $\mathrm{v} / \mathrm{v}$ ethanol(Merck)/water.

Metal solutions were made from their nitrate salts (Carlo Erba - Brazil) and their concentrations were determined by literature procedures ${ }^{27}$. The $\mathrm{Fe}$ (III) $0.01 \mathrm{~mol} \mathrm{~L}^{-1}$ solution was made in $0.03 \mathrm{~mol} \mathrm{~L}^{-1} \mathrm{HCl}$ (Merck) and the $\mathrm{H}^{+}$ ion content was determined by Gran's Plot. ${ }^{28}$

The aqueous KOH (Merck - Brazil) $0.1 \mathrm{~mol} \mathrm{~L}^{-1}$, carbonate-free solution was standardized against potassium hydrogen phthalate (Carlo Erba - Spain). $\mathrm{KNO}_{3}$ (Baker \& Adamson - USA) was the supporting electrolyte.

\section{Potentiometric measurements}

All potentiometric titrations were carried out under an inert atmosphere of water-KOH saturated nitrogen (WhiteMartins - Brazil) in a water-jacketed vessel maintained at $30.0 \pm 0.1{ }^{\circ} \mathrm{C}$ and $0.100 \mathrm{~mol} \mathrm{~L}^{-1}$ ionic strength $\left(\mathrm{KNO}_{3}\right)$. Four experiments were performed for each ligand studied. The first with the ligand alone to determine its protonation constants.

The others, with the ligand in the presence of the metal ion in the proportions ligand to metal, 1:1, 2:1 and 3:1.

The $\mathrm{pK}_{\mathrm{w}}$ was determined to be 13.63. A $20 \mathrm{~mL}$ Metrohm manual piston microburet tip was used to deliver the titrant $-\mathrm{CO}_{2}$ - free $\mathrm{KOH}$ standard, and the $\mathrm{p}[\mathrm{H}]^{28}$ values were directly measured with a Micronal (SP - Brazil) model B-375 pH meter, fitted with an Analyser (SP - Brazil) blue-glass and a saturated calomel reference electrode, calibrated with a standard strong acid $(\mathrm{HCl})$ to read $-\log \left[\mathrm{H}^{+}\right]$ directly, accuracy, $0.001 \mathrm{p}[\mathrm{H}]$ units.

The data obtained in the titrations were treated in a PC computer equipped with a Fortran program Best and the results displayed as a curve of species distribution with the aid of the program $\mathrm{SPE}^{28}$.

Two special potentiometric titrations were carried out in a solution obtained by mixing model compounds of NHA in the absence and in the presence of $\mathrm{Cu}^{2+}$. A quantity of 0.0717 millimole of 3-NPA and 4-NPA, 0.0540 millimole of 3-nitrosalicylic acid (3-NSA), 5-nitrosalicylic acid (5NSA) and 3,5-dinitrosalicylic acid (3,5-DNSA), and 0.0344 millimole of 4-nitrocatechol (4-NC) were titrated against $\mathrm{KOH}$. The second titration involved the same model compounds, in the above quantities, but with the inclusion of 0.0786 millimole of $\mathrm{Cu}^{2+}$.

\section{$U V$-visible measurements}

The aliquots analyzed by UV-VIS spectroscopy were taken at specific $\mathrm{p}[\mathrm{H}]$ values from a second potentiometric titration, specifically done for this purpose.

The UV-VIS spectra were taken with a Hewlett Packard model 8450A (USA) - Diode array spectrophotometer, from 260 to $600 \mathrm{~nm}$, using aliquots of a solution of ratio ligand to metal 3:1 of 3-NPA $\left(7.5 \times 10^{-4} \mathrm{~mol}\right.$ $\left.\mathrm{L}^{-1}\right)$ and $\mathrm{Fe}^{+3}\left(2.5 \times 10^{-4} \mathrm{~mol} \mathrm{~L}^{-1}\right)$, ionic strength $0.100 \mathrm{M}$ $\left(\mathrm{KNO}_{3}\right)$, using $1.000 \mathrm{~cm}$ quartz cells, at a controlled room temperature of $25.0^{\circ} \mathrm{C}$, and air in the reference beam. The $\mathrm{p}[\mathrm{H}]$ values of the experimental solutions were adjusted by adding small volumes of $0.1 \mathrm{~mol} \mathrm{~L}^{-1} \mathrm{KOH}$ with a $20 \mathrm{~mL}$ Metrohm piston microburet attached to the vessel.

\section{Cyclic voltammetric studies}

The electrochemical cell employed supported a $15 \mathrm{~mL}$ total volume of solution. It was maintained at $0.100 \mathrm{M}$ $\left(\mathrm{KNO}_{3}\right.$ - Merck - Brazil) ionic strength, sufficiently great to minimize solution resistance to charge flow through the cell, and to minimize migration as a means of mass transport to the electrode. The working electrode used was a glassy carbon of $2 \mathrm{~mm}$ diameter. The reference electrode was $\mathrm{Ag} / \mathrm{AgCl}$, and the auxiliary electrode was a platinum wire. The system, totally deoxygenated by a stream of pure nitrogen (White-Martins - Brazil), was connected to a cyclic voltammograph of Bioanalytical System Incorporation, model BAS-27 (USA), and the results were recorded in a BAS X-Y recorder. The potential values reported in this work were increased by $0.204 \mathrm{~V}$, and referred to normal hydrogen electrode $(\mathrm{NHE})^{29}$. The temperature was $25^{\circ} \mathrm{C}$, room-controlled.

The final concentration in the cell for both the ligand (4-NPA) and the metal ion, $\mathrm{Fe}^{+3}$, was $10^{-4} \mathrm{~mol} \mathrm{~L}^{-1}$ where the ligand to metal ratio was $1: 1 ; 0.5 \times 10^{-4} \mathrm{~mol} \mathrm{~L}^{-1}$ in the 2:1 solution, and $0.33 \times 10^{-4} \mathrm{~mol} \mathrm{~L}^{-1}$ in the $3: 1$ solution. 
The cyclic voltammograms were obtained as a function of each $\mathrm{p}[\mathrm{H}]$ value measured, using a glass electrode, $\mathrm{Ag} / \mathrm{AgCl}$ (Analyser - SP - Brazil), $5 \mathrm{~mm}$ diameter, placed into the electrochemical cell and a Corning pHmeter (UK), accuracy, $0.01 \mathrm{p}[\mathrm{H}]$ units. A Gilmont (USA) microburet delivered the required amount of $\mathrm{KOH}\left(0.1 \mathrm{~mol} \mathrm{~L}^{-1}\right)$ to reach to the desired $\mathrm{p}[\mathrm{H}]$ values.

The experimental conditions of the cyclic voltammograph were the following: a) range of swept potential was from $1.0 \mathrm{~V}$ to $-0.20 \mathrm{~V}$; b) scan rate $=10 \mathrm{mV} / \mathrm{s}$; and c) initial potential applied $=+1.0 \mathrm{~V}$.

\section{Results and Discussion}

The calculation of the equilibrium constants employed the microcomputer program $\mathrm{BEST}^{28}$. The results were also displayed in the form of species distribution diagrams with the aid of the program SPE ${ }^{28}$, with the metal concentration set at $100 \%$. The BEST program was designed to solve for the set of equilibrium constants corresponding to the model selected and also makes it possible to explore all aspects and variations of the model. The model used in this work involved the choice of the chemical species shown to be present from potentiometry, UV-Vis spectrophotometry and cyclic voltammetry data.

Each species concentration consists of a product of the overall stability constant $\left(\beta_{\mathrm{n}}\right)$ and individual component concentration raised to the power of its stoichiometric coefficient. The calculation of $\beta$ values continues until no further minimization of the standard deviation (s.d.), in $\mathrm{p}[\mathrm{H}]^{28}$ units, is obtained. The overall stability constants are defined by Eq. 4:

$$
\begin{aligned}
& \mathrm{M}^{+\mathrm{x}}+\mathrm{nL}^{2-} \rightleftharpoons \mathrm{ML}_{\mathrm{n}}^{(+\mathrm{x}-2 \mathrm{n})} \\
& \beta_{\mathrm{n}}=\frac{\left[\mathrm{ML}_{\mathrm{n}}^{(+\mathrm{x}-2 \mathrm{n})}\right]}{\left[\mathrm{M}^{\mathrm{x}+}\right]\left[\mathrm{L}^{2-}\right]^{\mathrm{n}}}
\end{aligned}
$$

All mathematical aspects of the programs employed have been reported elsewhere ${ }^{28,30}$, and the desired ionic strength was set in all experiments by following the literature $^{31}$.

The equilibrium constants for the hydrolysis species of the metal ions employed in the calculations of the overall formation constants $(\beta)$, were taken from the literature ${ }^{32}$. The following hydrolysis species were considered in the calculations: $\mathrm{Fe}(\mathrm{OH})^{2+}, \mathrm{Fe}(\mathrm{OH})_{2}{ }^{+}, \mathrm{Fe}(\mathrm{OH})_{3}, \mathrm{Fe}(\mathrm{OH})_{4}{ }^{-}$, $\mathrm{Fe}_{2}(\mathrm{OH})_{2}{ }^{4+}, \mathrm{Fe}_{3}(\mathrm{OH})_{4}{ }^{5+} ; \mathrm{Zn}(\mathrm{OH})^{+}, \mathrm{Zn}(\mathrm{OH})_{2}, \mathrm{Zn}(\mathrm{OH})_{3}{ }^{-}$, $\mathrm{Zn}(\mathrm{OH})_{4}{ }^{2-}$ and $\mathrm{CuOH}^{+}, \mathrm{Cu}(\mathrm{OH})_{2}, \mathrm{Cu}(\mathrm{OH})_{3}{ }^{-}, \mathrm{Cu}(\mathrm{OH})_{4}{ }^{2-}$, $\mathrm{Cu}_{2}(\mathrm{OH})_{2}$.

Figure 1 shows a potentiometric $\mathrm{p}[\mathrm{H}]$ profile of 3-NPA alone and in the presence of $\mathrm{Fe}^{+3}$ in the proportions of ligand to metal: 1:1, 2:1 and 3:1. Precipitation of hydrolysis products above $\mathrm{p}[\mathrm{H}]=4.5$ prevented further measurements of the metal systems. The protonation constants of the ligands 3-NPA and 4-NPA were determined under the same experimental conditions as for the complex formation constants in this work, $30.0 \pm 0.1{ }^{\circ} \mathrm{C}$ and ionic strength $0.100 \mathrm{M}\left(\mathrm{KNO}_{3}\right)$ in order to use them for further calculations.

These constants are presented in Table 1 as well as the results reported in the literature ${ }^{19-20,22-23}$ and also the values for the ligands derived from catechol and salicylic acid.

The values in Table 1 show that the most acidic compounds are the nitro- derivatives of phthalic acid, and the least acidic, catechol, as expected.

Many different methods of calculation and experimental approaches for determining apparent stability constants of $\mathrm{Cu}(\mathrm{II})$ and $\mathrm{HA}$ have been reported in the literature. One of them ${ }^{33}$ gives values for the binding constants of these kinds of complexes using a continuous distribution model based on the Scatchard plot, alternatively to the Bjerrum potentiometric titration method. The former method provided an average overall stability constant of 8.0 , at $25^{\circ} \mathrm{C}$, $\mu=0.005 \mathrm{~mol} \mathrm{~L}^{-1}$, concentration of $\mathrm{HA}=0.25 \mathrm{mg} \mathrm{mL}^{-1}$. The latter method employed gave the average values for the same kind of stability constant under the same conditions as 7.6. The main important feature was that $\mathrm{Cu}(\mathrm{II})$ reacts with more than one binding site, as the authors say, due to evidence for formation of $\mathrm{CuL}^{+}$and $\mathrm{CuL}_{2}$, where $\mathrm{L}$ is the reactive site of the macromolecule studied. The Bjerrum approach is suitable for this study but it does not account for the heterogeneous nature of HA. The Scatchard Plot gives rise to individual $\mathrm{K}$ values that are considered to reflect variations in binding energies without any regard to the nature in which $\mathrm{Cu}(\mathrm{II})$ is bound.

Another reported work ${ }^{34}$ dealt with the study of the formation constant for $\mathrm{HA}$ and $\mathrm{Cu}$ (II) by cross-polarization/magic angle spinning ${ }^{13} \mathrm{C}-\mathrm{NMR}$. The results of the average conditional constant was 11.6. All spectra con-

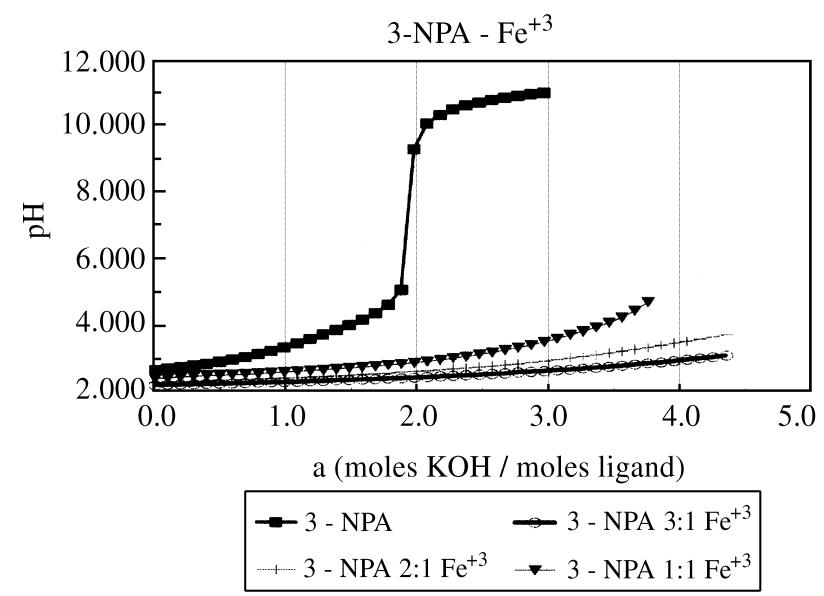

Figure 3. Potentiometric $\mathrm{p}[\mathrm{H}]$ profile of 3-nitrophthalic (3-NPA) acid and $\mathrm{Fe}^{3+} . \mathrm{a}=$ number of moles of ligand/number of moles of base. 1) 3-NPA $2.5 \times 10^{-4} \mathrm{~mol} \mathrm{~L}^{-1}$; 2) 3-NPA $5.0 \times 10^{-4} \mathrm{~mol} \mathrm{~L}^{-1}$ and Fe ${ }^{3+} 2.5 \times 10^{-4}$ mol L ${ }^{-1}$; 3) 3-NPA $7.5 \times 10^{-4} \mathrm{~mol} \mathrm{~L}^{-1}$ and $\mathrm{Fe}^{3+} 2.5 \times 10^{-4} \mathrm{~mol} \mathrm{~L}^{-1}$. 
tained one major peak in the carboxyl carbon region associated with the carboxylic acid carbon. There was a sharp difference among the HA employed although the values found for the binding constants were close.

In the trial titration that was carried out in this work using a mixture of nitrocompounds, models for nitrohumic substances, three protonation constants were observed due to the respective acidic groups. These groups were named $\mathrm{g}_{1}, \mathrm{~g}_{2}$, and $\mathrm{g}_{3}$ and their average values are recorded in Table 1. The $g_{1}$ acidic group was assigned to the nitrophthalic acids $^{22}, \mathrm{~g}_{2}$, to the nitrosalicylic acids ${ }^{19-20}$, and $\mathrm{g}_{3}$, to nitrocatechol $^{22}$. Table 2 presents the average formation constants calculated when the mixture of the nitro- models was titrated in the presence of a metal ion. $\mathrm{Cu}$ (II) was chosen because there is comprehensive data available in the literature. The data in the literature were required for the attempted assignment of value found in this titration with a proper basic site.

As can be seen from Table 1, the value for the formation constants for $\mathrm{CuL}$, $\mathrm{L}$ being the reactive site of the model, of around 3.6 was assigned to two ortho carboxyl groups in an aromatic ring, having a nitro substituent in the 3- and 4-C position (nitrophthalic acids); the value around 9.8 was assigned to one carboxyl and one hydroxyl group in ortho

Table 1. Protonation constants for the ligands phthalic acid (APA), 3- and 4-nitrophthalic acids (3-NPA and 4-NPA); catechol (CATEC), 3- and 4nitrocatechol (3-NC and 4-NC) respectively, and for the mixture of NPA (g1), NSA (g2) and 4-NC (g3).

\begin{tabular}{lcc}
\hline $\log \mathrm{K}$ & HL/H.L & $\mathrm{H}_{2} \mathrm{~L} / \mathrm{H} . \mathrm{HL}$ \\
\hline APA & $4.96^{\mathrm{a}}$ & $3.01^{\mathrm{a}}$ \\
& $4.92^{\mathrm{b}}$ & $2.76^{\mathrm{b}}$ \\
$3-\mathrm{NPA}$ & $3.98^{\mathrm{a}}$ & $2.19^{\mathrm{a}}$ \\
& $3.93^{\mathrm{b}}$ & $2.11^{\mathrm{c}}$ \\
4-NPA & $4.08^{\mathrm{a}}$ & $2.12^{\mathrm{a}}$ \\
& $4.12^{\mathrm{b}}$ & $2.02^{\mathrm{d}}$ \\
CATEC & $13.30^{\mathrm{e}}$ & $9.30^{\mathrm{f}}$ \\
$3-\mathrm{NC}$ & $11.83^{\mathrm{g}}$ & $6.48^{\mathrm{h}}$ \\
$4-\mathrm{NC}$ & $10.75^{\mathrm{I}}$ & $6.69^{\mathrm{j}}$ \\
g1 & $4.10^{\mathrm{a}}$ & - \\
$\mathrm{g} 2$ & $8.19^{\mathrm{a}}$ & - \\
$\mathrm{g} 3$ & $12.00^{\mathrm{a}}$ & - \\
\hline
\end{tabular}

${ }^{\mathrm{a}}$ this work; $30{ }^{\circ} \mathrm{C} ; \mu=0.100 \mathrm{~mol} \mathrm{~L}^{-1}\left(\mathrm{KNO}_{3}\right)$; s.d. $=0.01 ;{ }^{\mathrm{b}}$ reference 22 ; $25^{\circ} \mathrm{C} ; \mu=0.1 \mathrm{~mol} \mathrm{~L}^{-1}$; s.d. $=0.05 ;{ }^{\mathrm{c}}$ reference $22 ; 35^{\circ} \mathrm{C} ; \mu=0.0 \mathrm{~mol} \mathrm{~L}^{-1}$; s.d. $=$ not reported; ${ }^{\mathrm{d}}$ reference $22 ; 25{ }^{\circ} \mathrm{C} ; \mu=0.0 \mathrm{~mol} \mathrm{~L} \mathrm{~L}^{-1}$; s.d. $=$ not reported; ${ }^{\mathrm{e}}$ reference $22 ; 25^{\circ} \mathrm{C} ; \mu=0.1 \mathrm{~mol} \mathrm{~L}^{-1}$; s.d. $=0.3 ;{ }^{\mathrm{f}}$ reference 22 ; $25^{\circ} \mathrm{C} ; \mu=0.1 \mathrm{~mol} \mathrm{~L}^{-1}$; s.d. $=0.10 ;{ }^{\mathrm{g}}$ reference $22 ; 25^{\circ} \mathrm{C} ; \mu=0.1 \mathrm{~mol} \mathrm{~L}^{-1}$; s.d. $=0.40 ;{ }^{\mathrm{h}}$ reference $22 ; 25^{\circ} \mathrm{C} ; \mu=0.1 \mathrm{~mol} \mathrm{~L}^{-1}$; s.d. $=0.01 ;{ }^{\mathrm{i}}$ reference $22 ; 30{ }^{\circ} \mathrm{C} ; \mu=0.1 \mathrm{~mol} \mathrm{~L}^{-1}$; s.d. $=$ not reported; ${ }^{\mathrm{j}}$ reference $22 ; 25^{\circ} \mathrm{C} ; \mu=$ $0.1 \mathrm{~mol} \mathrm{~L}^{-1}$; s.d. $=0.03$. positions in an aromatic ring (nitrosalicylic acids); the value near 11.5 was assigned to two ortho phenolic hydroxyl groups (nitrocatechol). The basic group assigned to the nitrophthalic acids has exhibited a greater basicity towards $\mathrm{Cu}^{2+}$, as it has a larger formation constant when present in the mixture of the model compounds, than when alone with the $\mathrm{Cu}^{2+}$. The same was true of the nitrosalicylic basic sites. The basic group due to nitrocatecholate behaves the same, no matter only with the metal ion or in the mixture of the model compounds employed.

Looking at these results one can infer that there are some interactions among the basic sites of the nitro-models employed when they are mixed in solution. This feature can be explained by the fact that when in a mixture, the less basic ligands will change the way they interact with metals by the presence of other more basic sites in their vicinities. This maybe the case in a related publication ${ }^{34}$ where a value of around 11.0 was assigned to a carboxylic basic site, without taking into account the vicinity. A further related work $^{33}$ has revealed consistent data with those in this present work.

Tables 3, 4 and 5 list the formation constants for the complexing systems in the presence of $\mathrm{Fe}(\mathrm{III})$ and $\mathrm{Zn}(\mathrm{II})$, and the ligands derived from phthalic (Table 3), salicylic

Table 2. Equilibrium constants for the titration of the mixture of model compounds NPA, g1, NSA, g2, and 4-NC, g3, and the metal ion $\mathrm{Cu}^{2+}$, in the proportion 1:1, metal to total ligand concentration ratio.

\begin{tabular}{lcc}
\hline & $\log \mathrm{K}$ & $\mathrm{Cu}^{2+}$ \\
\hline $\mathrm{g} 1$ & ML/M.L & $3.67^{\mathrm{a}}$ \\
$\mathrm{g} 2$ & MHL/ML.H & $3.37^{\mathrm{a}}$ \\
$\mathrm{g} 3$ & ML/M.L & $9.80^{\mathrm{a}}$ \\
3-NPA & MHL/ML.H & $3.71^{\mathrm{a}}$ \\
4-NPA & ML/M.L & $11.50^{\mathrm{a}}$ \\
3-NC & ML/M.L & $2.42^{\mathrm{b}}$ \\
4-NC & ML/M.L & $2.42^{\mathrm{b}}$ \\
& ML/M.L & $12.74^{\mathrm{b}}$ \\
3-NSA & ML/M.L & $11.68^{\mathrm{b}}$ \\
& MHL/ML.H & $0.81^{\mathrm{b}}$ \\
5-NSA & ML/M.L & $8.1^{\mathrm{c}}$ \\
& MHL/ML.H & $3.7^{\mathrm{c}}$ \\
3,5-DNSA & ML/M.L & $8.3^{\mathrm{c}}$ \\
& MHL/ML.H & $2.9^{\mathrm{c}}$ \\
\hline
\end{tabular}

${ }^{\mathrm{a}}$ this work; $30{ }^{\circ} \mathrm{C} ; \mu=0.100 \mathrm{~mol} \mathrm{~L}^{-1}\left(\mathrm{KNO}_{3}\right)$; s.d. $=0.03 ;{ }^{\mathrm{b}}$ reference 22 ; $25^{\circ} \mathrm{C} ; \mu=0.1 \mathrm{~mol} \mathrm{~L}^{-1}$; s.d. $=$ not reported; ${ }^{\mathrm{c}}$ reference $20 ; 30{ }^{\circ} \mathrm{C} ; \mu=0.100$ $\mathrm{mol} \mathrm{L}^{-1}\left(\mathrm{KNO}_{3}\right)$ s.d. $=0.1 ;{ }^{\mathrm{d}}$ reference $20 ; 30^{\circ} \mathrm{C} ; \mu=0.100 \mathrm{~mol} \mathrm{~L}^{-1}\left(\mathrm{KNO}_{3}\right)$ s.d. $=0.3$ 
acids (Table 4) and from catechol (Table 5). Values compiled from the literature have been indicated ${ }^{19-20,22-23}$.

From the Tables it can be seen that the complexes of both metal ions and the nitro- compounds are weaker than the respective complexes with non nitro- compounds, an exception being $\mathrm{Zn}^{2+}$ with APA and with NPA. The effect of stabilization of the complexes by the delocalization of charges in the aromatic ring by nitro- substituents can be seen by analyzing the constants in Table 3 for the ligands studied and the metal ions $\mathrm{Fe}^{3+}$ and $\mathrm{Zn}^{2+}$.

When looking at the constants for 3-nitrophthalic (3NPA) and 4-nitrophthalic (4-NPA) acids with $\mathrm{Fe}^{3+}$, it is seen that the values for the formation constants $\mathrm{ML}, \mathrm{ML}_{2}$ and $\mathrm{ML}_{3}$ are almost the same for both ligands. The non nitro- ligand phthalate, being more basic than the nitrocompounds, has larger formation constant values with respect to the same metal ion.

It is also possible to make an evaluation of the differences in the values of the formation constants between a non-nitro model compound and each one of their nitroderivatives. Analysis of the results in Table 3 by subtracting the stability constants for APA - $\mathrm{Fe}^{3+}$ from 3-NPA - $\mathrm{Fe}^{3+}$ :

$$
\Delta \log \mathrm{K}_{1}=6.1-4.3=1.8
$$

Table 3. Equilibrium constants for the systems of the ligands phthalic acid (APA) and 3-nitrophthalic and 4-nitrophthalic acids (3-NPA and 4-NPA) with the metal ions $\mathrm{Fe}(\mathrm{III})$ and $\mathrm{Zn}(\mathrm{II})$.

\begin{tabular}{lcccc}
\hline Metal ion & $\log \mathrm{K}$ & APA & $3-\mathrm{NPA}$ & $4-\mathrm{NPA}$ \\
\hline $\mathrm{Fe}^{+3}$ & ML/M.L & $6.07^{\mathrm{a}}$ & $4.3^{\mathrm{b}}$ & $4.4^{\mathrm{b}}$ \\
& ML2/ML.L & $4.49^{\mathrm{a}}$ & $3.6^{\mathrm{b}}$ & $4.0^{\mathrm{b}}$ \\
& $\mathrm{ML}_{3} / \mathrm{ML}_{2} . \mathrm{L}$ & $2.70^{\mathrm{a}}$ & $2.2^{\mathrm{b}}$ & $2.2^{\mathrm{b}}$ \\
$\mathrm{Zn}^{+2}$ & ML/M.L & $2.2^{\mathrm{d}}$ & $3.33^{\mathrm{c}}$ & $2.5^{\mathrm{b}}$ \\
& ML2/ML.L & $2.0^{\mathrm{e}}$ & - & $2.3^{\mathrm{b}}$ \\
\hline
\end{tabular}

${ }^{\mathrm{a}}$ this work, $30{ }^{\circ} \mathrm{C} ; \mu=0.100 \mathrm{~mol} \mathrm{~L}^{-1}\left(\mathrm{KNO}_{3}\right)$; s.d. $=0.04 ;{ }^{\mathrm{b}}$ this work, 30 ${ }^{\circ} \mathrm{C} ; \mu=0.100 \mathrm{~mol} \mathrm{~L}^{-1}\left(\mathrm{KNO}_{3}\right)$; s.d. $=0.2 ;{ }^{\mathrm{c}}$ reference $22,35^{\circ} \mathrm{C} ; \mu=0.0$ mol L ${ }^{-1}$; s.d. $=$ not reported; ${ }^{\mathrm{d}}$ reference $22,25^{\circ} \mathrm{C} ; \mu=0.1 \mathrm{~mol} \mathrm{~L}^{-1}$; s.d.= not reported; ${ }^{\mathrm{e}}$ reference $22,25^{\circ} \mathrm{C} ; \mu=0.0 \mathrm{~mol} \mathrm{~L}^{-1}$; s.d. $=$ not reported.
$\Delta \log \mathrm{K}_{2}=4.5-3.6=0.9$

$\Delta \log \mathrm{K}_{3}=2.7-2.2=0.5$ and for APA $-\mathrm{Fe}^{3+}$ and 4-NPA $-\mathrm{Fe}^{3+}$ then the results are:

$\Delta \log \mathrm{K}_{1}=6.1-4.4=1.7$

$\Delta \log \mathrm{K}_{2}=4.5-4.0=0.5$

$\Delta \log \mathrm{K}_{3}=2.7-2.2=0.5$

$\mathrm{K}_{1}, \mathrm{~K}_{2}$ and $\mathrm{K}_{3}$ being formation constants of the species ML, $\mathrm{ML}_{2}$ and $\mathrm{ML}_{3}$ respectively.

Using the same methodology to subtract the formation constant values for the systems APA and 3-NPA, this time for the metal ion $\mathrm{Zn}(\mathrm{II})$ :

$\Delta \log \mathrm{K}_{1}=2.2-3.3=-1.1$

$\Delta \log \mathrm{K}_{2}=$ not available

and for APA - $\mathrm{Zn}^{2+}$ and 4-NPA - $\mathrm{Zn}^{2+}$ :

$\Delta \log \mathrm{K}_{1}=2.2-2.5=-0.3$

$\Delta \log \mathrm{K}_{2}=2.0-2.3=-0.3$.

Normally, the decrease in the protonation constant is accompanied by a decrease in the metal - ligand binding constant. As the Fe(III) ion, a hard Lewis acid, forms the

Table 5. Equilibrium constants for the systems of the ligands catechol (CATEC), 3-nitrocatechol and 4-nitrocatechol ( 3-NC and 4-NC).

\begin{tabular}{lcccc}
\hline metal ion & $\log \mathrm{K}$ & CATEC & 3-NC & 4-NC \\
\hline $\mathrm{Fe}^{+3}$ & ML/M.L & $20.4^{\mathrm{a}}$ & n.a & $15.53^{\mathrm{b}}$ \\
& ML2/ML.L & $15.0^{\mathrm{a}}$ & n.a & $13.11^{\mathrm{b}}$ \\
& ML3/ML2.L & $9.4^{\mathrm{a}}$ & n.a & - \\
$\mathrm{Zn}^{+2}$ & ML/M.L & $9.9^{\mathrm{c}}$ & $8.64^{\mathrm{b}}$ & $8.20^{\mathrm{b}}$ \\
& $\mathrm{ML}_{2} / \mathrm{ML} . \mathrm{L}$ & $7.5^{\mathrm{c}}$ & $7.16^{\mathrm{b}}$ & $6.80^{\mathrm{b}}$ \\
\hline
\end{tabular}

${ }^{\mathrm{a}}$ reference $23,25^{\circ} \mathrm{C} ; \mu=0.1 \mathrm{~mol} \mathrm{~L}^{-1}$; s.d. = not reported; ${ }^{\mathrm{b}}$ reference 22 , $25{ }^{\circ} \mathrm{C} ; \mu=0.1 \mathrm{~mol} \mathrm{~L}-1 ;$ s.d. $=$ not reported; ${ }^{\mathrm{c}}$ reference $22,25{ }^{\circ} \mathrm{C} ; \mu=0.1$ mol L ${ }^{-1} ;$ s.d. $=0.2 ;$ n.a $=$ non available data.

Table 4. Equilibrium constants for the systems of the ligands salicylic acid (SALA), 3-nitrosalicylic acid (3-NSA), 5-nitrosalicylic acid (5-NSA) and 3,5-dinitrosalicylic acid (3,5-DNSA) with the metal ions Fe(III) and Zn(II).

\begin{tabular}{lccccc}
\hline Metal ion & $\log \mathrm{K}$ & SALA & 3-NSA & 5-NSA & 3,5-DNSA \\
\hline $\mathrm{Fe}^{+3}$ & ML/M.L & $16.3^{\mathrm{a}}$ & $13.4^{\mathrm{b}}$ & $13.9^{\mathrm{b}}$ & $9.8^{\mathrm{b}}$ \\
& ML $/$ ML.L & $11.9^{\mathrm{a}}$ & $9.5^{\mathrm{b}}$ & $10.2^{\mathrm{b}}$ & $7.4^{\mathrm{b}}$ \\
& ML $/$ ML $2 . \mathrm{L}$ & $7.8^{\mathrm{a}}$ & $7.3^{\mathrm{b}}$ & $8.3^{\mathrm{b}}$ & $3.1^{\mathrm{b}}$ \\
$\mathrm{Zn}^{+2}$ & ML/M.L & $6.85^{\mathrm{c}}$ & $5.1^{\mathrm{d}}$ & $5.3^{\mathrm{d}}$ & $3.8^{\mathrm{d}}$ \\
& ML $/$ ML.L & & $4.0^{\mathrm{d}}$ & $3.9^{\mathrm{d}}$ & $2.7^{\mathrm{d}}$ \\
\hline
\end{tabular}

${ }^{\mathrm{a}}$ reference $22,25^{\circ} \mathrm{C} ; \mu=0.1 \mathrm{~mol} \mathrm{~L}^{-1}$; s.d. $=0.02 ;{ }^{\mathrm{b}}$ reference $19,30^{\circ} \mathrm{C} ; \mu=0.100 \mathrm{~mol} \mathrm{~L}^{-1}\left(\mathrm{KNO}_{3}\right) ;$ s.d. $=0.1 ;{ }^{\mathrm{c}}$ reference $22,20^{\circ} \mathrm{C} ; \mu=0.1 \mathrm{~mol} \mathrm{~L}{ }^{-1}$; s.d. $=$ not reported; ${ }^{\mathrm{d}}$ reference $20,30^{\circ} \mathrm{C} ; \mu=0.100 \mathrm{~mol} \mathrm{~L}^{-1}\left(\mathrm{KNO}_{3}\right)$; s.d. $=0.1$. 
complexes $\mathrm{ML}_{2}{ }^{-}$and $\mathrm{ML}_{3}{ }^{3-}$, which bear negative charges, with the nitrocompounds, the $\log \mathrm{K}_{2,3}$ values diminish. This can be attributed to the inductively withdrawing electron effect of the nitro- groups in the NPA compounds resulting in better stabilization of the net negatively charged species, compared to the $\log \mathrm{K}$ values obtained for $\mathrm{ML}^{+}$. Electrostatic effects have been attributed to some metal/ligand interactions in the literature ${ }^{15}$.

The same effect is enhanced when the metal ion being complexed to the phthalic derivative is $\mathrm{Zn}^{2+}$, a softer Lewis acid. The nitrophthalic acids effectively withdraw the negative charges that the $\mathrm{ML}_{2}{ }^{2-}$ complexes bear, and the $\Delta \mathrm{log}$ $\mathrm{K}_{2}$ becomes negative. Here, this effect is observed even in the neutral complex formed, ML, where metal to ligand ratio is $1: 1$.

The use of nitro- substituted aromatic compounds allows testing of the influence not only the inductive effect, which plays a minor role in the stabilization of the complexed and uncomplexed species, but also of the resonance effect. Resonance effects play no role in the catechol and in some salicylate derivatives. When in a mixture, the less basic ligands will change the way they interact with metals by the presence of other more basic sites in their vicinities. The observed effect in this work was an enhancement in the ability of complexation by the less basic nitro- model compounds employed towards $\mathrm{Cu}^{2+}$.

Figures 2, 3 and 4, the species distribution diagrams for the ion $\mathrm{Fe}^{+3}$ and APA, 3-NPA and 4-NPA, are shown respectively. The three encountered species, $\mathrm{ML}, \mathrm{ML}_{2}$ and $\mathrm{ML}_{3}$ are formed and destroyed at $\mathrm{p}[\mathrm{H}]$ values below 6.0 for 3-NPA and 4-NPA, and above $\mathrm{p}[\mathrm{H}] 5.0$ for 4-NPA and 4.5 for 3-NPA the hydrolytic species predominates. However for APA and the same metal ion, $\mathrm{ML}_{3}$ species predominate at $\mathrm{p}[\mathrm{H}]$ values from 2.6 to 8.7 .

The species distribution diagrams of $\mathrm{Zn}^{+2}$ and catechol, $\mathrm{Zn}^{+2}$ and 3-NC and $\mathrm{Zn}^{+2}$ and 4-NC are shown in Figs. 5, 6 and 7, respectively. The formation of the complexed species ML begins above $\mathrm{p}[\mathrm{H}]=5.0$ for 3-NC and 4-NC. For catechol, this species only starts to be formed at $\mathrm{p}[\mathrm{H}]$ values above 6.0. The same happens for $\mathrm{ML}_{2}$, which in the case of the nitrocatechols appear around $\mathrm{p}[\mathrm{H}]=6.0$, and for catechol and the same metal ion, only after $\mathrm{p}[\mathrm{H}]$ near 8.0. Under soil solution conditions $(\mathrm{p}[\mathrm{H}]$ near 7.0) almost all the $\mathrm{Zn}^{+2}$ metal ion is complexed by the nitrocatechols, while for catechol, this complexation reaches only $15 \%$ of the total metal ion as the ML complex (Fig. 5).

Higher $\mathrm{p}[\mathrm{H}]$ values for the species formation was noticed in the systems involving nitrosalicylic acids when compared to salicylic acid towards complexation of $\mathrm{Fe}^{3+}$ and $\mathrm{Zn}^{2+19,20}$.

A cyclic voltammetric $\mathrm{p}[\mathrm{H}]$ dependence study was carried out with 4-NPA and $\mathrm{Fe}^{3+}$. Figure 8 shows the cyclic voltammogram for 4-NPA ( not electrochemically active)

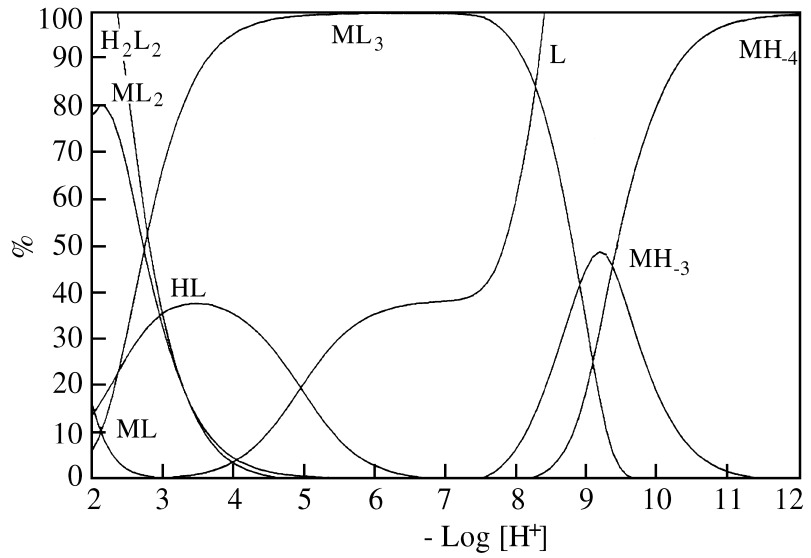

Figure 4. Species distributions for $\mathrm{Fe}^{3+}$ (M) $2.5 \times 10^{-3} \mathrm{~mol} \mathrm{~L}^{-1}$ and the ligand phthalic acid (APA) (L), $7.5 \times 10^{-3} \mathrm{~mol} \mathrm{~L}^{-1}$ from $\mathrm{p}[\mathrm{H}] 2.0$ to 12.0 . $\%$ is percentage of a species present, with the metal concentration set at $100 \%$. H-x represents $(\mathrm{OH})_{\mathrm{x}}{ }^{-}$.

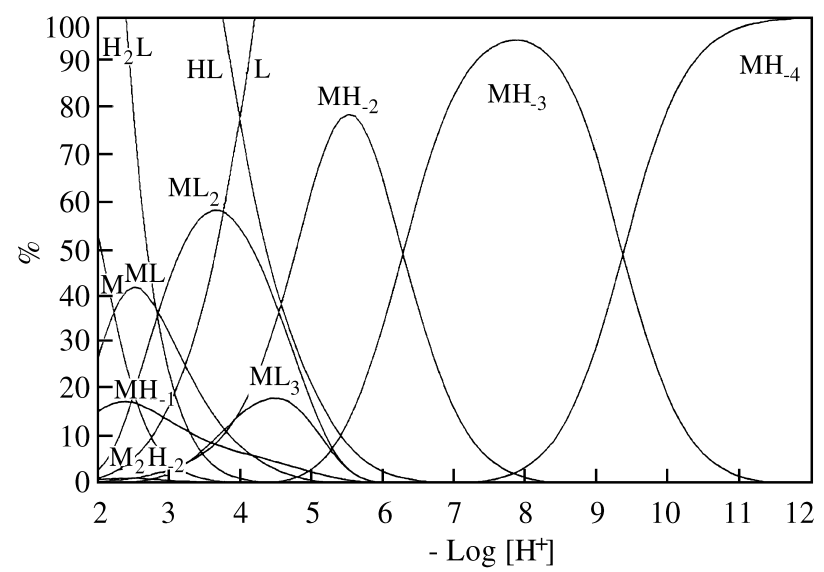

Figure 5. Species distributions for $\mathrm{Fe}^{3+}$ (M) $2.5 \times 10^{-3} \mathrm{~mol} \mathrm{~L}^{-1}$ and the ligand 3-nitrophthalic acid (3-NPA) (L), $7.5 \times 10^{-3} \mathrm{~mol} \mathrm{~L}^{-1}$ from $\mathrm{p}[\mathrm{H}] 2.0$ to $12.0 . \%$ is percentage of a species present, with the metal concentration set at $100 \%$. $\mathrm{H}_{-\mathrm{x}}$ represents $(\mathrm{OH})_{\mathrm{x}}{ }^{-}$.

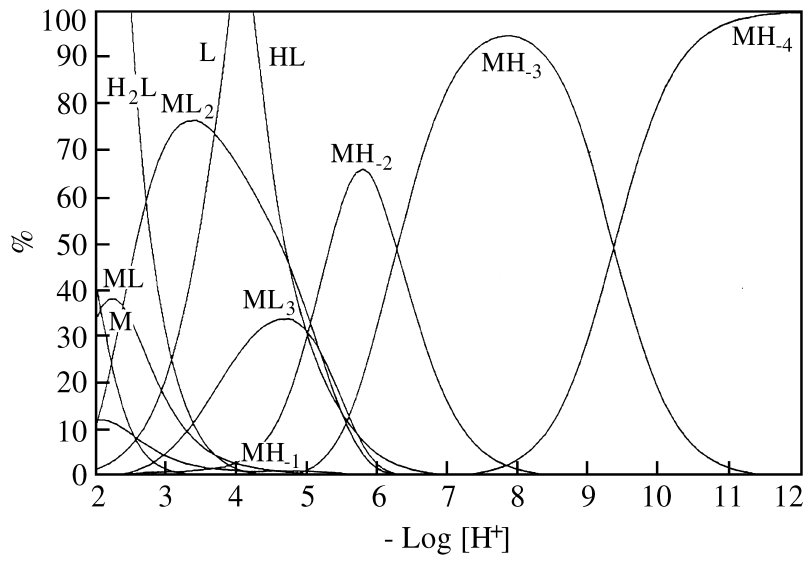

Figure 6. Species distributions for $\mathrm{Fe}^{3+}$ (M) $2.5 \times 10^{-3} \mathrm{~mol} \mathrm{~L}^{-1}$ and the ligand 4-NPA (L), $7.5 \times 10^{-3} \mathrm{~mol} \mathrm{~L}^{-1}$ from $\mathrm{p}[\mathrm{H}] 2.0$ to $12.0 . \%$ is percentage of a species present, with the metal concentration set at $100 \%$. $\mathrm{H}_{-\mathrm{x}}$ represents $(\mathrm{OH})_{\mathrm{x}}{ }^{-}$. 
and $\mathrm{Fe}^{3+}$. The metal ion $\mathrm{Zn}^{2+}$ and its complexes with 4-NPA were not electrochemically active.

The Nernst equation provides useful information for redox reactions involving simultaneous proton and electron-transfer processes. The number of protons $(\mathrm{m})$ and electrons (n) involved in the electrode surface reactions are described as follows:

$$
\mathrm{Ox}+\mathrm{ne}^{-}+\mathrm{mH}^{+} \stackrel{\mathrm{K}}{\rightleftharpoons} \mathrm{Red}
$$

where, $\mathrm{K}$ is equilibrium constant and $\mathrm{Ox}$ and Red are the oxidised and reduced species, respectively.

Taking into account that the concentration of protons at the electrode surface is the same as that of the bulk solution, it is feasible to write Eq. 6:

$$
\mathrm{E}_{\mathrm{p}}=\mathrm{E}^{\Theta}-\frac{0.059}{\mathrm{n}} \log \left(\frac{\mathrm{D}_{\mathrm{ox}}}{\mathrm{D}_{\mathrm{RED}}}\right)^{1 / 2}-0.059 \frac{\mathrm{m}}{\mathrm{n}} \mathrm{p}[\mathrm{H}]
$$

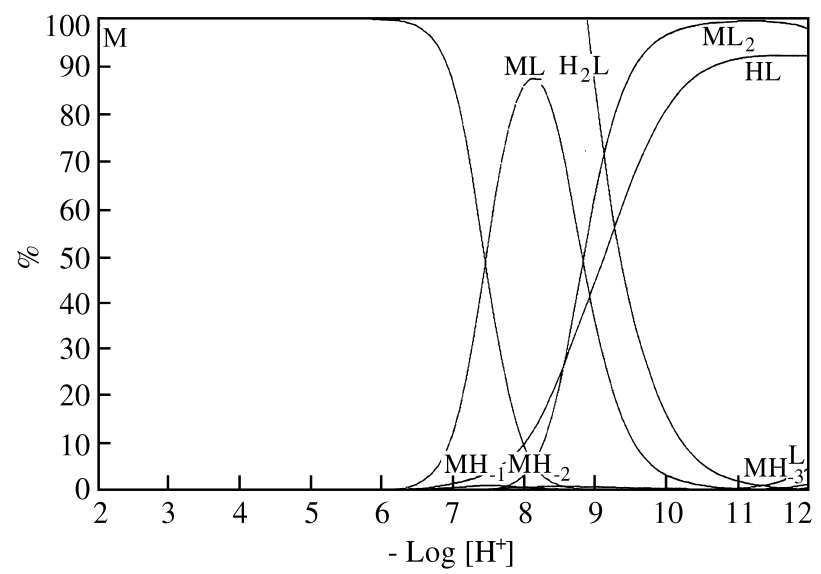

Figure 7. Species distributions for $\mathrm{Zn}^{2+}$ (M) $2.5 \times 10^{-3} \mathrm{~mol} \mathrm{~L}^{-1}$ and the ligand catechol (CATEC)(L), $7.5 \times 10^{-3} \mathrm{~mol} \mathrm{~L}^{-1}$ from $\mathrm{p}[\mathrm{H}] 2.0$ to $12.0 . \%$ is percentage of a species present, with the metal concentration set at $100 \%$. $\mathrm{H}_{-\mathrm{x}}$ represents $(\mathrm{OH})_{\mathrm{x}}{ }^{-}$.

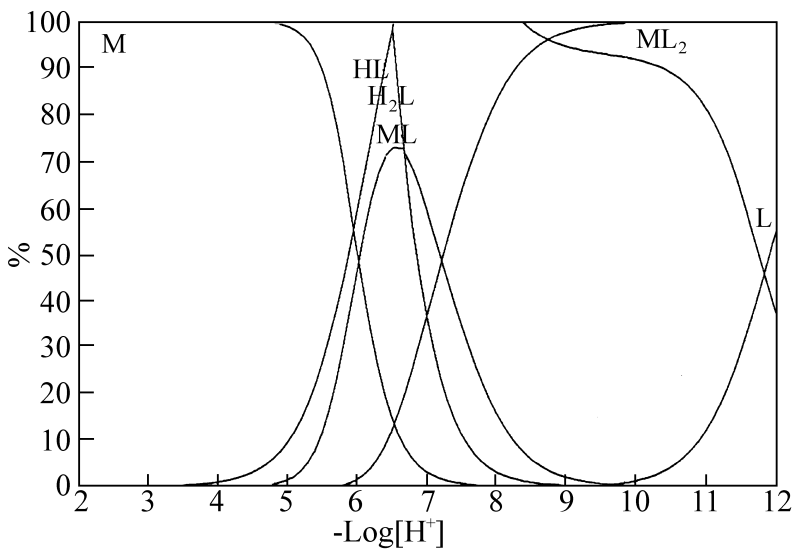

Figure 8. Species distributions for $\mathrm{Zn}^{2+}$ (M) $2.5 \times 10^{-3} \mathrm{~mol} \mathrm{~L}^{-1}$ and the ligand 3-nitrocatechol (3-NC)(L), 7.5 x 10 $0^{-3} \mathrm{~mol} \mathrm{~L}^{-1}$ from $\mathrm{p}[\mathrm{H}] 2.0$ to 12.0. $\%$ is percentage of a species present, with the metal concentration set at $100 \%$. $\mathrm{H}_{\text {-x }}$ represents $(\mathrm{OH})_{\mathrm{x}}{ }^{-}$. where $\mathrm{E}^{\Theta}$ is the formal electrode potential, $\mathrm{D}_{\mathrm{ox}}$ and $\mathrm{D}_{\mathrm{RED}}$ are the diffusion coefficients for oxidised and reduced species respectively. Equation 7 also applies to the system studied:

$$
\mathrm{E}_{\mathrm{p}}=0.5\left(\mathrm{E}_{\mathrm{pc}}+\mathrm{E}_{\mathrm{pa}}\right)
$$

where, $\mathrm{E}_{\mathrm{pc}}$ and $\mathrm{E}_{\mathrm{pa}}$ is the cathodic and anodic peak potential, respectively. Assuming that $\mathrm{D}_{\mathrm{ox}}=\mathrm{D}_{\mathrm{RED}}$, Equation 6 can be simplified into Eqs. 8 or 9

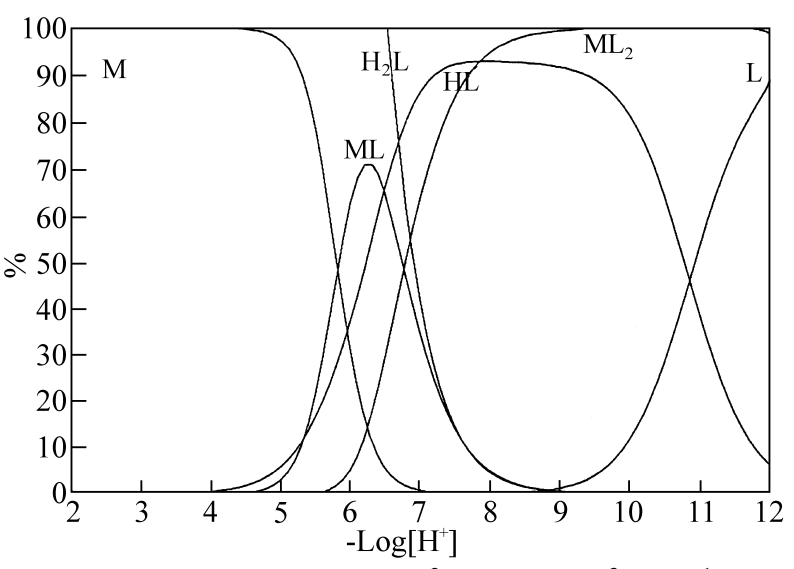

Figure 9. Species distributions for $\mathrm{Zn}^{2+}$ (M) $2.5 \times 10^{-3} \mathrm{~mol} \mathrm{~L}^{-1}$ and the ligand 4-nitrocatechol (4-NC)(L), $7.5 \times 10^{-3} \mathrm{~mol} \mathrm{~L}^{-1}$ from $\mathrm{p}[\mathrm{H}] 2.0$ to 12.0 . $\%$ is percentage of a species present, with the metal concentration set at $100 \%$. $\mathrm{H}_{-\mathrm{x}}$ represents $(\mathrm{OH})_{\mathrm{x}}{ }^{-}$.

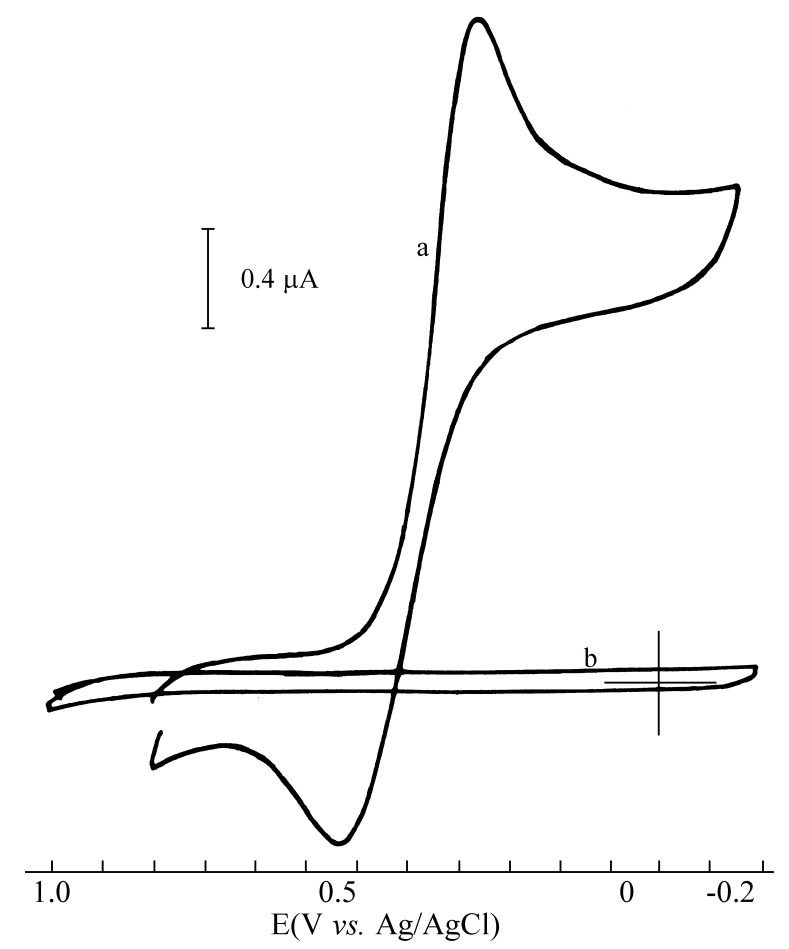

Figure 10. Cyclic voltammogram (-0.01 V/s) of a) $\mathrm{Fe}\left(\mathrm{H}_{2} \mathrm{O}\right) 6^{3+} 1.0 \times 10^{-4}$ $\mathrm{mol} \mathrm{L}^{-1}$ and b) 4-NPA, $1.0 \times 10^{-4} \mathrm{~mol} \mathrm{~L}^{-1}$. From E/V 1.000 to $-0.200 \mathrm{~V}$, in $\mathrm{KNO}_{3} 0.10 \mathrm{~mol} \mathrm{~L}^{-1}, 25^{\circ} \mathrm{C}$. 


$$
\begin{aligned}
& E_{p}=E^{\theta}-0.059 \frac{m}{n} p[H] \\
& E_{p}=\left(E^{\theta}-0.0295\right)-0.059 \frac{m}{n} p[H]
\end{aligned}
$$

Since both $\left[\mathrm{Fe}^{\mathrm{III}}\left(4-\mathrm{NPA}^{=}\right)\left(\mathrm{H}_{2} \mathrm{O}\right)_{4}\right]^{+}, \mathrm{ML}$, and $\left[\mathrm{Fe}^{\mathrm{III}}(4-\right.$ $\left.\mathrm{NPA}^{2-}\right)_{2}\left(\mathrm{H}_{2} \mathrm{O}\right)_{2}$ ], $\mathrm{ML}_{2}$, were only stable in acidic aqueous solution, the formal reduction potential was determined by cyclic voltammetry, over a $\mathrm{p}[\mathrm{H}]$ range of 2.0 to 5.0 .

The two cathodic peaks that can be seen in Figs. 9, 10 and 11 , the cyclic voltammograms obtained from 4-NPA and $\mathrm{Fe}(\mathrm{III})$ at 1:1, 1:2 and 1:3 metal to ligand ratios, attested the existence of two electroactive species at the electrode surface. The more cathodic peaks, quasi-reversible voltammograms, were assigned as being the aquo species and the irreversible peaks were assigned as being due to ML species(Fig. 9) and $\mathrm{ML}_{2}$ species (Figs. 10 and 11).

Considering Eqs. 8 and 9 and a pseudo-reversible process for the system studied, it was possible to determine the formal electrode potential. The potentials $\mathrm{E}_{\mathrm{pc}}$ and $\mathrm{E}_{\mathrm{p}}$ data (Table 6) were then plotted against every measured $\mathrm{p}[\mathrm{H}]$ value (Figs. 12, 13 and 14) for the three voltammetric titrations, where $1: 1,1: 2$ and 1:3 ratios of metal to ligand were employed.

The formal electrode potential $\mathrm{E}^{\Theta}=+0,635( \pm 0,050) \mathrm{V}$ $v s$. NHE for the reduction of $\mathrm{ML}$ and $\mathrm{ML}_{2}$ species were the same and were obtained by the linear coefficient of Eq. 9 considering also the standard deviations calculated in the plots in Figs. 12, 13 and 14.

The values of the angular coefficient of Eq. 9, 0.115, indicated that all processes involved two protons and one electron, being transferred in the heterogeneous reaction at the surface electrode.

The EC mechanism observed for the irreversible reduction (more anodic peak) was probably due to decomposition of the complexed species formed according to the proposed Eqs. 10 to 13 below:

$$
\begin{aligned}
& \begin{array}{c}
\mathrm{E}:\left[\mathrm{Fe}^{\mathrm{III}}\left(4-\mathrm{NPA}^{=}\right)\left(\mathrm{H}_{2} \mathrm{O}\right)_{4}\right]^{+}+2 \mathrm{H}^{+}+\mathrm{e}^{-} \longrightarrow \\
{\left[\mathrm{Fe}^{\mathrm{II}}\left(4-\mathrm{NPAH}_{2}\right)\left(\mathrm{H}_{2} \mathrm{O}\right)_{4}\right]^{2+}}
\end{array} \\
& \mathrm{C}:\left[\mathrm{Fe}^{\mathrm{II}}\left(4-\mathrm{NPAH}_{2}\right)\left(\mathrm{H}_{2} \mathrm{O}\right)_{4}\right]^{2+} \longrightarrow \\
& \left.\mathrm{E}:\left[\mathrm{Fe}^{\mathrm{III}}\left(4-\mathrm{NPAH}^{-}\right)_{2}\left(\mathrm{H}_{2} \mathrm{O}\right)_{2}\right]^{+}+2 \mathrm{Fe}^{+}+\mathrm{e}\left(\mathrm{H}_{2} \mathrm{O}\right)_{6}\right]^{2+} \longrightarrow \\
& {\left[\mathrm{Fe}^{\mathrm{II}}\left(4 \mathrm{NPAH}_{2}\right)_{2}\left(\mathrm{H}_{2} \mathrm{O}\right)_{2}\right]^{2+}}
\end{aligned}
$$

\begin{tabular}{|c|c|c|c|c|c|c|c|c|}
\hline \multirow[t]{2}{*}{$\mathrm{p}[\mathrm{H}]$} & \multicolumn{2}{|c|}{ Species 4-NPA 1:1 Fe ${ }^{3+}$} & \multirow[t]{2}{*}{$\mathrm{p}[\mathrm{H}]$} & \multicolumn{2}{|c|}{ Species 4-NPA 2:1 Fe ${ }^{3+}$} & \multirow[t]{2}{*}{$\mathrm{p}[\mathrm{H}]$} & \multicolumn{2}{|c|}{ Species 4-NPA 3:1 Fe $3+$} \\
\hline & $\mathrm{E}_{\mathrm{pc}}^{\mathrm{d}}(\mathrm{V})$ & $\overline{\mathrm{E}}_{\mathrm{p}}^{\mathrm{e}, \mathrm{f}}(\mathrm{V})$ & & $\mathrm{E}_{\mathrm{pc}}^{\mathrm{d}}(\mathrm{V})$ & $\overline{\mathrm{E}}_{\mathrm{p}}^{\mathrm{e}, \mathrm{f}}(\mathrm{V})$ & & $\mathrm{E}_{\mathrm{pc}}{ }^{\mathrm{d}}(\mathrm{V})$ & $\overline{\mathrm{E}}_{\mathrm{p}}^{\mathrm{e}, \mathrm{f}}(\mathrm{V})$ \\
\hline 2.20 & - & 0.694 & 2.22 & - & 0.659 & 2.00 & - & 0.624 \\
\hline 2.51 & 0.434 & 0.649 & 2.51 & 0.410 & 0.614 & 2.50 & 0.389 & 0.614 \\
\hline 2.71 & 0.374 & 0.617 & 2.92 & 0.414 & 0.627 & 3.15 & 0.354 & 0.594 \\
\hline 2.90 & 0.324 & 0.612 & 3.19 & 0.384 & 0.612 & 3.72 & 0.279 & 0.584 \\
\hline 3.12 & 0.314 & 0.607 & 3.51 & 0.349 & 0.609 & 4.23 & 0.259 & 0.541 \\
\hline 3.71 & 0.259 & - & 3.85 & 0.289 & 0.592 & 4.65 & 0.184 & - \\
\hline 4.48 & 0.144 & - & 4.33 & 0.159 & - & 5.21 & 0.134 & - \\
\hline
\end{tabular}

It was not possible to determine the species [FeIII(4$\left.\left.\mathrm{NPA}_{2}^{-}\right)_{3}\right]^{3-}, \mathrm{ML}_{3}$, by voltammetry due to the formation of insoluble hydrolysis products at $\mathrm{p}[\mathrm{H}]$ near 5.0. These insol-

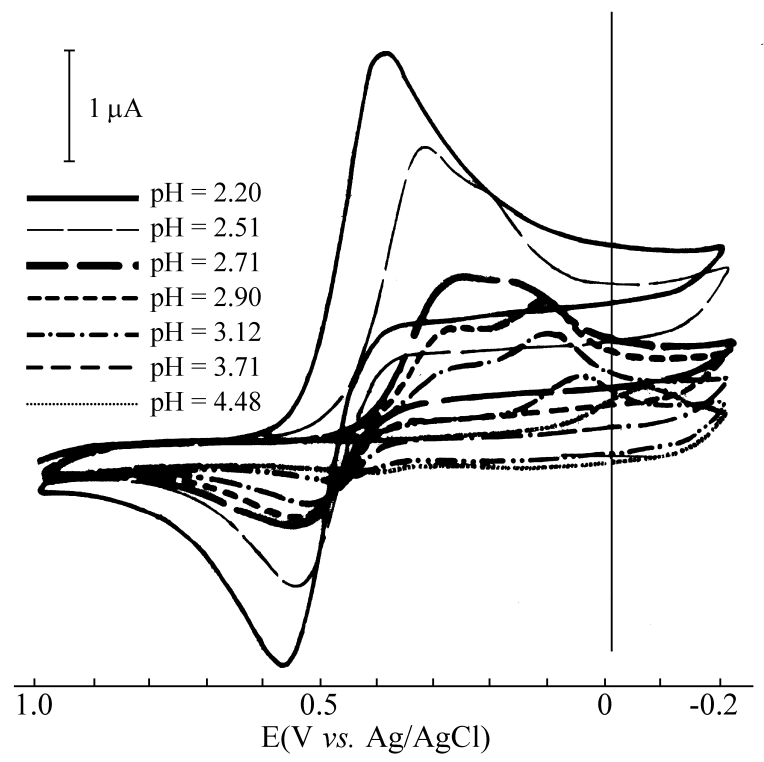

Figure 11. Cyclic voltammogram $(-0.01 \mathrm{~V} / \mathrm{s})$ of $4-\mathrm{NPA}$ in the presence of $\mathrm{Fe}^{3+}$ both at $1.0 \times 10^{-4} \mathrm{~mol} \mathrm{~L}^{-1}$ at $\mathrm{p}[\mathrm{H}]$ values, $2.20,2.51,2.71,2.90$, 3.12 and 4.48. From E/V 1.000 to $-0.200 \mathrm{~V}$, in $\mathrm{KNO}_{3} 0.10 \mathrm{~mol} \mathrm{~L}^{-1}, 25^{\circ} \mathrm{C}$.

Table 6. Electrochemical data ${ }^{\mathrm{a}, \mathrm{b}, \mathrm{c}}$ dependence of $\mathrm{p}[\mathrm{H}]$ for the 1:1, 2:1 and 3:1 ratios of ligand 4-NPA to metal ${ }^{\mathrm{c}}$ at $25^{\circ} \mathrm{C}$ and $\mu=0,10 \mathrm{M} \mathrm{KNO}$.

(a)Potentials are $v s$. NHE; (b)Scan rate $0,01 \mathrm{~V} \mathrm{~s}^{-1}$; (c)Solute concentration $\sim 10^{-3} \mathrm{M}$; (d) $\mathrm{E}_{\mathrm{pc}}$; (e) $\mathrm{E}_{1 / 2}$ is the average of cathodic and anodic peak potentials; (f)The peak-to-peak separation $\left(\Delta \mathrm{E}_{\mathrm{p}}\right)$ values are bigger the higher $\mathrm{p}[\mathrm{H}]$ values. 


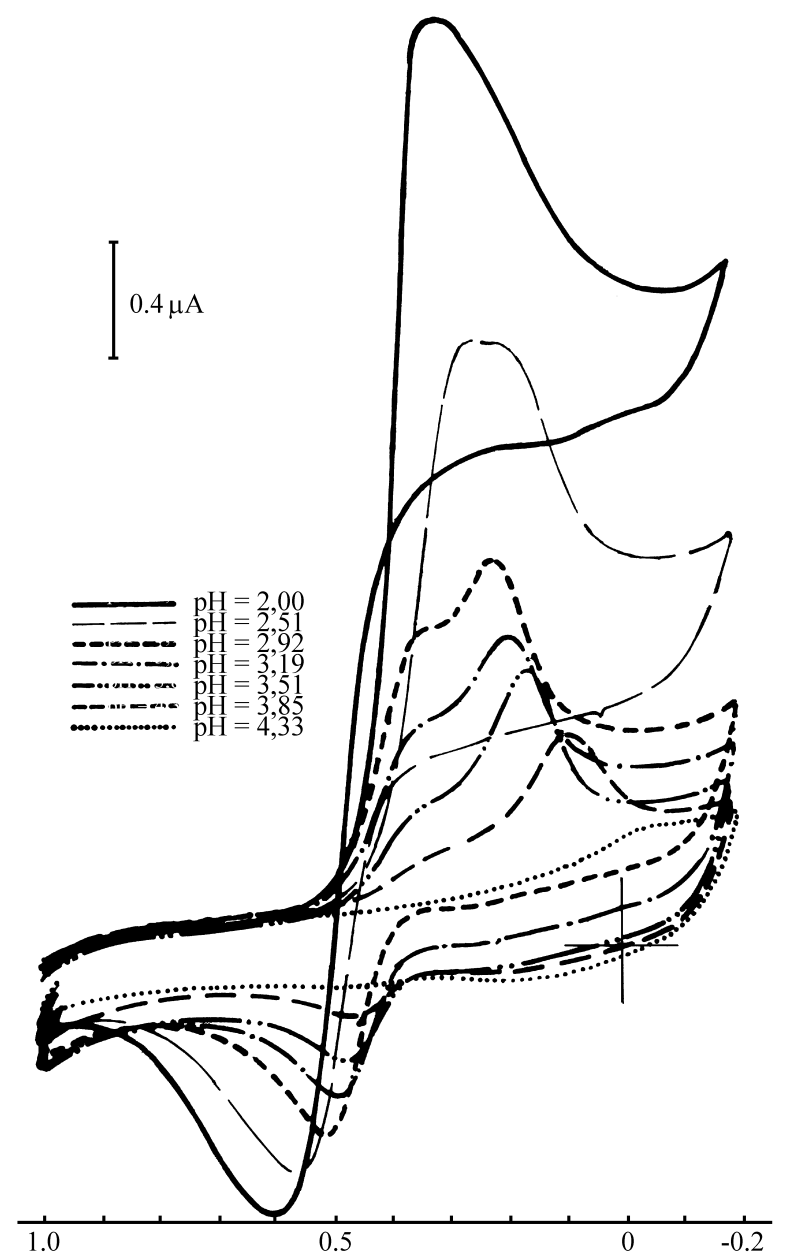

Figure 12. Cyclic voltammogram (-0.01 V/s) of 4-NPA $2.0 \times 10^{-4} \mathrm{~mol}$ $\mathrm{L}^{-1}$ in the presence of $\mathrm{Fe}^{3+}, 1.0 \times 10^{-4} \mathrm{~mol} \mathrm{~L}^{-1}$ at $\mathrm{p}[\mathrm{H}]$ values, 2.00, 2.51, $2.92,3.19,3.51,3.85$ and 4.33 . From $\mathrm{E} / \mathrm{V} 1.000$ to $-0.200 \mathrm{~V}$, in $\mathrm{KNO}_{3}$ $0.10 \mathrm{~mol} \mathrm{~L}^{-1}, 25^{\circ} \mathrm{C}$.

uble products happened to be present in the same region of $\mathrm{p}[\mathrm{H}]$ that the $\mathrm{ML}_{3}$ begins to be formed (Fig. 4).

Useful information from the UV-Vis spectra of the NPA ligands and $\mathrm{Fe}^{+3}$ and $\mathrm{Zn}^{2+}$ could not be obtained due to a mixture of all species over the observed $\mathrm{p}[\mathrm{H}]$ range.

\section{Conclusions}

As interest in the study of complexation between ligands from soil and water towards metal ions is increasing, many questions arise about such a complex system. The speciation study is making progress as new techniques give support ${ }^{35}$. But one cannot give up studying the basic chemical aspects on how the metal ion interacts with HS, as these materials vary in structure from place to place where they are formed.

Model compounds can give an insight into how some basic sites of HS complex metal ions and can also overcome

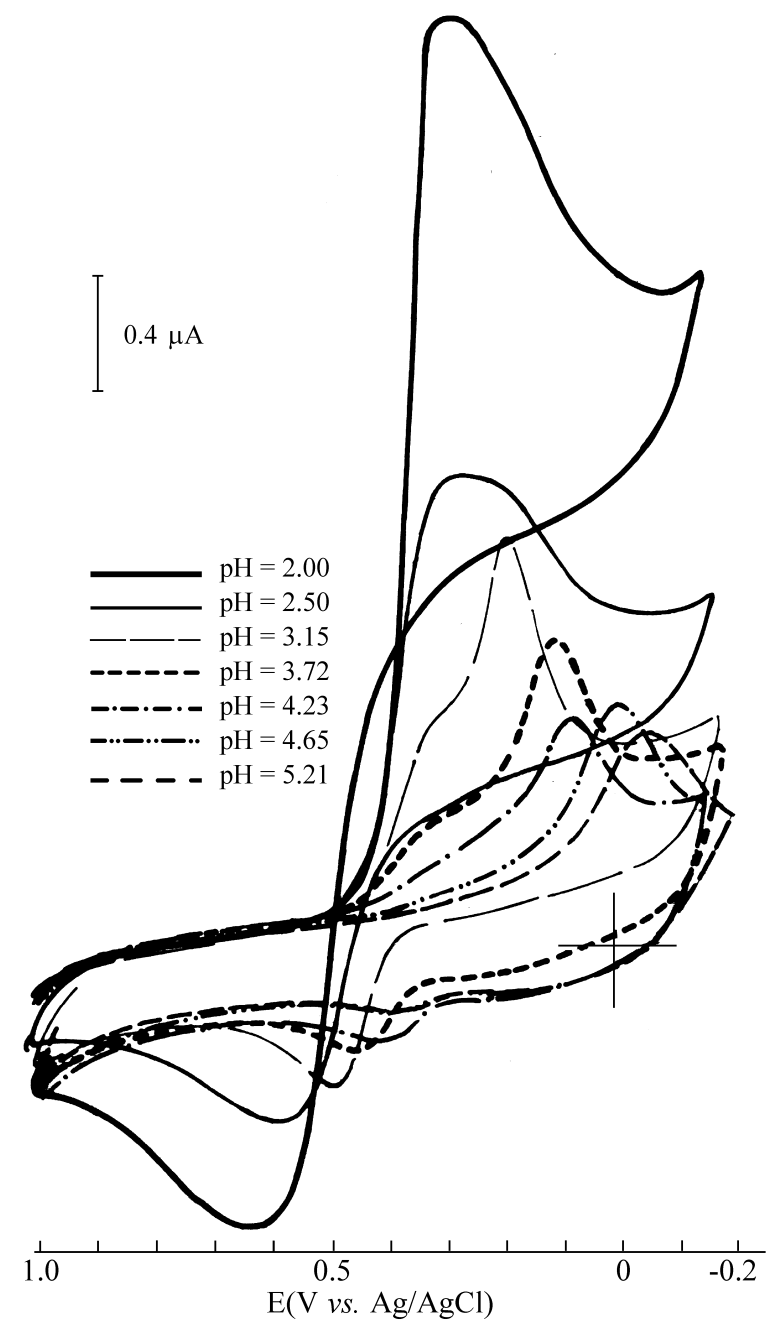

Figure 13. Cyclic voltammogram (-0.01 V/s) of 4-NPA $3.0 \times 10^{-4} \mathrm{~mol}$ $\mathrm{L}^{-1}$ in the presence of $\mathrm{Fe}^{3+}, 1.0 \times 10^{-4} \mathrm{~mol} \mathrm{~L}^{-1}$ at $\mathrm{p}[\mathrm{H}]$ values, 2.00, 2.50, $3.15,3.72,4.23,4.65$ and 5.21. From E/V 1.000 to $-0.200 \mathrm{~V}$, in $\mathrm{KNO}_{3}$ $0.10 \mathrm{~mol} \mathrm{~L}^{-1}, 25^{\circ} \mathrm{C}$.

the main difficulties encountered in obtaining equilibrium constants for complex ligands.

Model compounds can also be studied by other commonly available techniques such as UV-VIS Spectroscopy and Cyclic Voltammetry, giving more specific information, where studying the whole complex organic material itself, would not be possible. Although the UV-Vis Spectroscopy technique was not very useful in the present study of nitrophthalic acids mainly due to all species being present over the $\mathrm{p}[\mathrm{H}]$ range investigated, as the nitrophthalates are not very strong Lewis bases, it is a useful technique for detecting different species which exist in equilibrium. Cyclic voltammetry has shown the formation and destruction of the proposed species in each equilibrium studied as a function of increasing $\mathrm{p}[\mathrm{H}]$. All species proposed by potentiometric titrations and their assigned formation and destruction $\mathrm{p}[\mathrm{H}]$ values were in perfect agreement with the cyclic voltammograms obtained. 


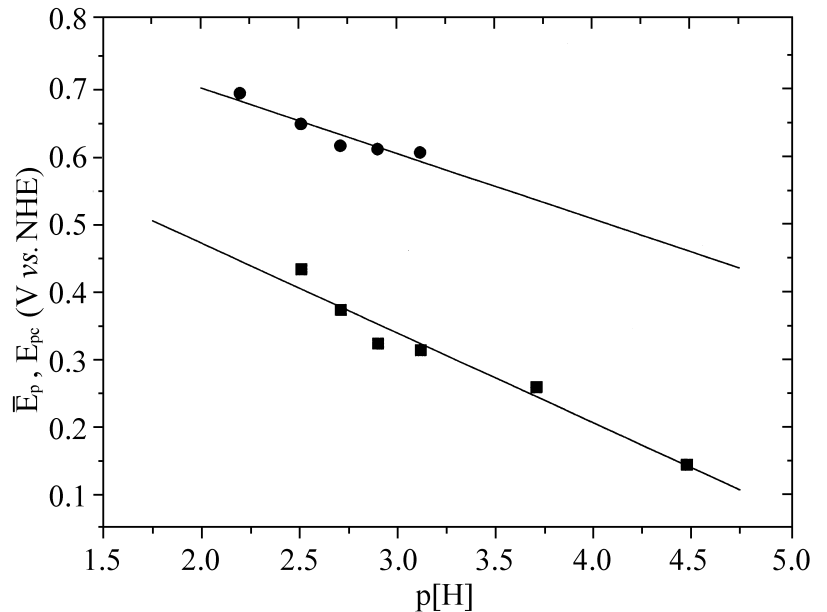

Figure 14. Plot of $\mathrm{E}_{\mathrm{p}}$ and $\mathrm{E}_{\mathrm{pc}}(\mathrm{V}) v s . \mathrm{p}[\mathrm{H}]$ for the set of cyclic voltammograms obtained for 4-NPA $3.0 \times 10^{-4} \mathrm{~mol} \mathrm{~L}^{-1}$, and $\mathrm{Fe}^{3+} 1.0 \times 10^{-4} \mathrm{~mol}$ $\mathrm{L}^{-1}$, in the ratio $1: 1$ metal to ligand.

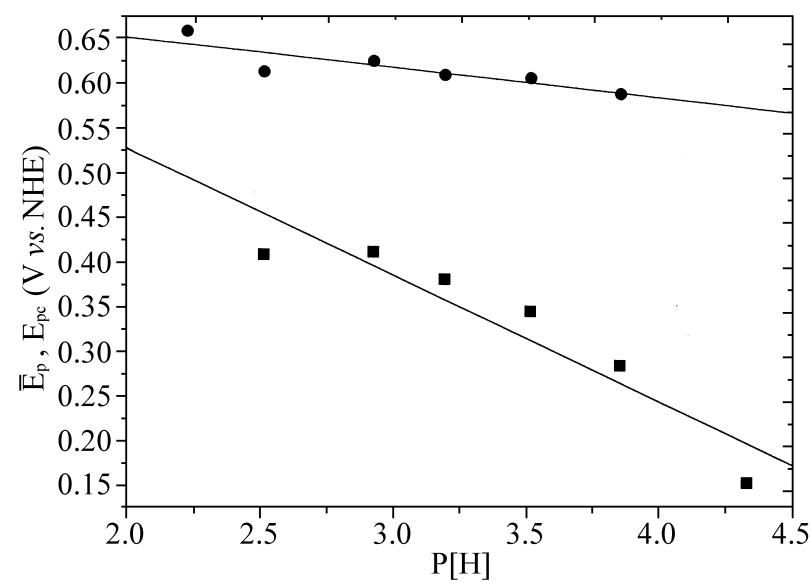

Figure 15. Plot of $\mathrm{E}_{\mathrm{p}}$ and $\mathrm{E}_{\mathrm{pc}}(\mathrm{V})$ vs. $\mathrm{p}[\mathrm{H}]$ for the set of cyclic voltammograms obtained for 4-NPA $3.0 \times 10^{-4} \mathrm{~mol} \mathrm{~L}^{-1}$, and $\mathrm{Fe}^{3+} 1.0 \times 10^{-4} \mathrm{~mol}$ $\mathrm{L}^{-1}$, in the ratio $1: 2$ metal to ligand.

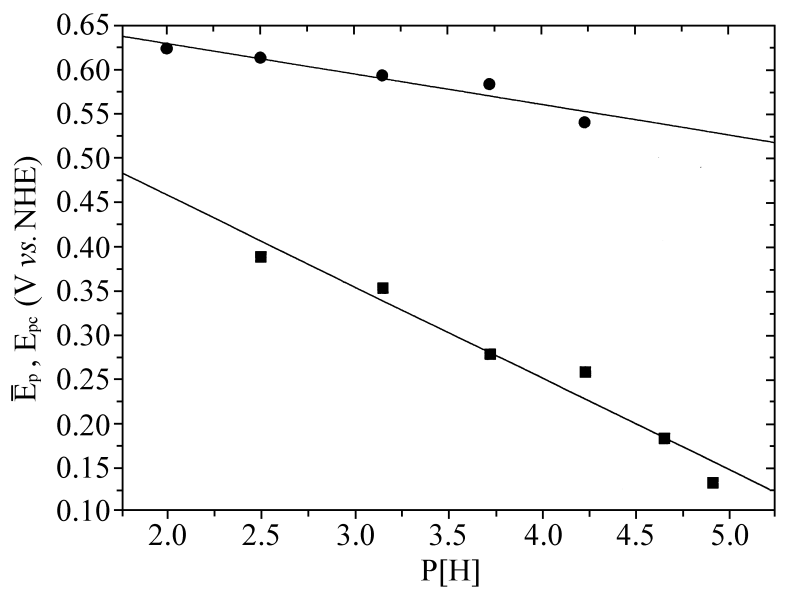

Figure 16. Plot of $\mathrm{E}_{\mathrm{p}}$ and $\mathrm{E}_{\mathrm{pc}}(\mathrm{V}) v s . \mathrm{p}[\mathrm{H}]$ for the set of cyclic voltammograms obtained for 4-NPA $3.0 \times 10^{-4} \mathrm{~mol} \mathrm{~L}^{-1}$, and Fe $\mathrm{F}^{3+} 1.0 \times 10^{-4} \mathrm{~mol}$ $\mathrm{L}^{-1}$, in the ratio $1: 3$ metal to ligand.
The nitrophthalic acids, models of metal ion binding sites of NHA employed in this work, are more effective for complexing the plant micronutrient Zinc (II), a softer Lewis acid than the harder Iron (III) acid. As was shown with the nitrophthalic, nitrosalicylic and nitrocatechol compounds there is a good possibility that the NHS is more effective than HS in complexing micronutrients in general, as these various NHS binding sites are more versatile for the complexation of soft and hard metal ions. This sheds new light on the possibility of using NHS as a slow-release fertilizer.

When mixed, the model compounds showed that their complexing ability towards a metal ion can be altered by the presence of a diversity of basic sites in their neighborhood. The formation constants for a model compound and the metal ion $\mathrm{Cu}$ (II) differed when it was determined alone with the metal ion, and when this same model compound was mixed with other model compounds.

Much more work remains to be done in this field, but the present work is certainly an initial proof that other approaches to studying the interaction of HA and metal ions ought to be developed.

\section{References}

1. Schnitzer, M.; Khan, S.U. Humic Substances in the Environment; Marcel Dekker: New York, 1972.

2. Perdue, E.M. Geochim. et Cosmochim. Acta 1978, 42, 1351.

3. Cabaniss, S.E. Anal. Chim. Acta 1991, 255, 23.

4. Van Dijk, H. Geoderma 1971, 5, 53.

5. Shulten, H.-R.; Schnitzer, M. Naturwissenschaften 1993, 80, 29.

6. Gamble, D.S.; Schnitzer, M.; Hoffman, I. Can. J. Chem. 1970, 48, 3197.

7. Tipping, E.; Backes, C.A.; Hurley, M.A. Wat. Res. 1988, 22, 597.

8.Sohn, M.L.; Hughes, M.C. Geochim et Cosmochim. Acta 1981, 45, 2393.

9. Mangrich, A.S.; Vugman, N.V. Fuel 1990, 69, 925.

10. Schnitzer, M. Soil Sci. 1991, 151, 41.

11. Marinsky, J.A.; Gupta, S.; Schindler, P. J. Colloid Interface Sci. 1982, 89, 401.

12. Cabaniss, S.E.; Shuman, M.S. Geochim et Cosmochim. Acta 1988, 52, 185.

13. Powell, H.K.J.; Town, R.M. Anal. Chim. Acta 1992, 267, 47.

14. Town, R.M.; Powell, H.K.J. Anal. Chim. Acta 1993, 279, 221.

15. Stevenson, F.J.; Fitch, A.; Brar, M.S. Soil Sci. 1993, $155,77$.

16. Warwick, P.; Hall, A.; Patterson, M. Radiochim. Acta 1992, 58/59, 137.

17. Tipping, E.; Woof, C.; Hurley, M.A. Wat. Res. 1991, 25,425 . 
18. Ephraim, J.E.; Allard, B. In Ion Exchange and Solvent Extraction; J.A.; Marcus, Y., Eds., Marinsky, Marcel Dekker: New York, 1993; vol II, p 335.

19. Mercê, A.L.R.; Mangrich, A.S.; Szpoganicz, B.; Levy, N.M.; Felcman, J. J. Braz. Chem. Soc. 1996, 7, 97.

20. Mercê, A.L.R.; Mangrich, A.S.; Szpoganicz, B.; Levy, N.M. J. Braz. Chem. Soc. 1996, 7, 239.

21. Kiss, T.; Atkári, K.; Bojczuk, M.J.; Decock, P. J. Coord. Chem. 1993, 29, 81.

22. Martell, A.E.; Smith, R.M. NIST Critical Stability Constants of Metal Complexes, NIST Database 46, Gaithersburg, MD, USA, 1994; and references cited therein.

23. Martell, A.E.; Smith, R.M. Critical Stability Constants, Plenum Press: New York, 1982, vol 5: 1st supplement, and references cited therein.

24. Garret, T.M.; Miller, P.W.; Raymond, K.N. Inorg. Chem. 1989, 28, 128.

25. Shriver, D.F.; Atkins, P.W.; Langford, C.H. Inorganic Chemistry; Oxford University Press: U.K., 2nd Ed., 1994; pp 288-291.
26. Harris,D.C.; Bertolucci, M.D. Symmetry and Spectroscopy. An Introduction to Vibrational and Eletronic Spectroscopy; Dover Publications, Inc.: New York, USA, 1978

27. Schwarzenbach, G.; Flaschka, H. Complexometric Titrations; Methuen \& CO LTD: London, UK, 1968, pp 192,264

28. Martell, A.E.; Motekaitis, R.J. The Determination and Use of Stability Constants; VCH: New York, 2nd Ed., 1992.

29. Heineman, W.R. J.Chem. Ed. 1983, 60, 305.

30. Rosso, N.D.; Szpoganicz, B.; Motekaitis, R.J.; Martell, A.E. Inorg. Chim. Acta 1994, 227, 49.

31. Lewis, G.H.; Randall, M.J. J. Am. Chem. Soc. 1921, $43,1112$.

32. Baes Jr, C.F.; Mesmer, R.E. The Hydrolysis of Cations; John-Wiley \& Sons: New York, USA, 1976; pp 122, 293.

33. Stevenson, F.J.; Fitch, A.; Brar, M.S. Soil Sci. 1993, 155(2), 77.

34. Sohn, M.; Weese, D. Marine Chem. 1986, 20, 61.

35. Langford, C.H.; Cook, R.L. Analyst 1995, 120, 591, and references cited therein. 